\title{
Expression pattern of immune- and cancer-associated genes in peripheral blood of mice bearing melanoma cells
}

\author{
G. V. Gerashchenko*, I. M. Vagina*, Yu. V. Vagin, Z. Yu. Tkachuk, V. I. Kashuba \\ Institute of Molecular Biology and Genetics, NAS of Ukraine \\ 150, Akademika Zabolotnoho Str., Kyiv, Ukraine, 03143 \\ g.v.gerashchenko@imbg.org.ua \\ * These Authors contributed equally for this work.
}

\begin{abstract}
Aim. To identify putative non-invasive expression markers, based on relative expression (RE) of cancer- and immune-associated genes, in peripheral blood of mice, bearing melanoma cells. Methods. RE of 56 cancer- and immune-associated genes was assessed byquantitative PCR in peripheral blood of C57BL/6j mice inoculated with B16 mouse melanoma cells and in control animals. Results. Eleven genes showed significant differences in the RE levels in mice,bearing melanoma: six genes (Ccl5, Il1b, Mif, Rnasel, S100al and Tgfbl) were expressed at higher levels, and five genes (Erbb2, Ifnb1, Il6, Pdcdl and Proml) were downregulated in comparison with the control animals. We have demonstrated a stable immunosuppressed state of mice inoculated with melanoma cells as evidenced by decreased RE levels of $I f n b I$ and $P d c d l$ and increased RE levels of Lbp, Tlr3, Tlr8, Gstp1, Prom1, Oas1a, Oas3 and Illb. Conclusions. Assessment of expression of cancer- and immune-associated genes in peripheral blood during growth of malignant cells in experimental animals may result in discovery of effective noninvasive expression markers for the prognosis of the cancer outcome and chemotherapy efficiency.
\end{abstract}

Ke y w o r d s: melanoma, relative gene expression, immune-associated genes, putative expression markers

\section{Introduction}

Melanoma represents high malignant neoplasms. It occurs in a variety of tumor groups that differ in clinical and histological characteristics, profiles of metastasis, ethnic distribution, a causative role of UV radiation and mutational profile for each patient [1]. For now, such modern approaches to cure mela noma as immunotherapy [2] and combined methods [3] are widely used; however, none of them provides $100 \%$ efficiency of treatment. Melanoma, like many solid tumors, is a quite heterogeneous disease with certain molecular features of individual tumors, hence, it is important, to define the markers for progno-

(C) 2019 G. V. Gerashchenko et al.; Published by the Institute of Molecular Biology and Genetics, NAS of Ukraine on behalf of Biopolymers and Cell. This is an Open Access article distributed under the terms of the Creative Commons Attribution License (http://creativecommons.org/licenses/by/4.0/), which permits unrestricted reuse, distribution, and reproduction in any medium, provided the original work is properly cited 
sis, describing a status of immune system and specific characteristics of each tumor $[4,5,6]$. The least invasive methods to analyze markers are preferential. The analysis of liquid biopsies (blood, urine, saliva, etc.) is the most non-invasive for this purpose.

To characterize the growth of tumor cells in experimental animals, 56 cancer-associated genes and several immune-associated genes were chosen, namely, the genes encoding cytokines (Ifna2, Ifnb1, Ifne, Ifnk, Ifng, Il6, Illb, Il12a, Tnf), chemokines (Ccl3, Ccl4, Ccl5, Cxcl9, Cxcl10, Cxcl11), interferon-stimulated genes (Oas1a, Oas2, Oas3, Mx1, Tlr3, Tlr7, Tlr8, Rela), immune therapy target genes (Pdcd1, Cd274), markers of cancerous cells (Prom1, Nfkb1, Gstpl, Tgfbl) and genes involved in inflammation (Nlrp3, Arg2, Mif, S100A1, Xdh et al.)[7].

Many of these genes are expressed differently in various cell types, that is why it is quite difficult to correlate their RE levels with the tumor progression.

We hypothesized a possibility to find the correlation between the RE levels of abovementioned genes and the growth of melanoma cells in mice, using the peripheral blood of experimental animals to monitor the expression. We wanted to detect the specific changes in the RE levels and propose the novel noninvasive expression markers for the cancer diagnosis and prognosis.

\section{Materials and Methods}

Cell line. The mouse melanoma B16 cell line was obtained from the Bank of Cell Lines (R.E.Kavetsky IEPOR, NAS of Ukraine). The cells were cultured in DMEM (Sigma) medium with the addition of $10 \%$ FBS (Sigma),
100 units $/ \mathrm{ml}$ penicillin and $100 \mu \mathrm{g} / \mathrm{ml}$ streptomycin at $37^{\circ} \mathrm{C}$ in a $\mathrm{CO}_{2}$ incubator. The cells were detouched by an EDTA/trypsin solution and rinsed in a phosphate buffered saline (PBS). Cells were counted, and suspension of $2 \times 10^{5}$ cells was injected into each mouse.

Experimental animals. Adult female mice of the C57BL/6j line were used. Suspension of the B16 mouse melanoma cell was subcutaneously introduced into the right posterior paw. Mice, not bearing melanoma cells, served as the control animals. Five mice were studied in each group. On the day $19^{\text {th }}$ following the injection of melanoma cells, the peripheral blood was collected for the analysis. All manipulations with animals were conducted in accordance with the rules of handling of experimental animals, approved by the Bioethic Committee of IMBG of NAS of Ukraine and the rules, described in "European Convention for the Protection of Vertebrate Animals used for experimental and other scientific purposes" (Strasburg, 1986).

Total RNA isolation and cDNA synthesis. $100 \mu \mathrm{l}$ of whole blood were thoroughly mixed with $300 \mu \mathrm{l}$ of Trizol (Sigma). Total RNA was isolated, using a Direct-zol RNA MiniPrep total RNA kit (Zymo Research), according to the manufacturer's protocol. DNaseI treatment was performed on columns. The quality and concentration of total RNA samples were analyzed on spectrophotometer (NanoDrop Technologies Inc. USA) and agarose gel electrophoresis. cDNA synthesis was performed, using Maxima First Strand cDNA Synthesis Kit for RT-qPCR (Thermo Scientific, USA), according to the manufacturer's protocol.

Quantitative PCR ( $q P C R$ ). The RE levels of the investigated genes were assessed as 
described earlier [8, 9], using 5x HOT FIREPolEvaGreen qPCR Mix Plus (Solis BioDyne, Estonia) on Bio-Rad CFX96 RealTime PCR Detection System (USA) and the following program: denaturing $-95^{\circ} \mathrm{C}$ for 12 min and then 40 cycles $\left(95^{\circ} \mathrm{C}-15 \mathrm{~s}, 60^{\circ} \mathrm{C}-20\right.$ $\left.\mathrm{s}, 72^{\circ} \mathrm{C}-20 \mathrm{~s}\right)$. Primers were selected, using an algorithm https://www.ncbi.nlm.nih.gov/ tools/primer-blast/ and the databases https:// primerdepot.nci.nih.gov/ and https: //www. origene.com (see [10]). The reference TBP gene was used to normalize RE calculations by $2^{\wedge}-\mathrm{dCt}$ and $2^{\wedge}$-ddCt methods, as described earlier [9].

Statistical analysis. A STATISTICA10 software was used to perform the statistical analysis. The Kruskal-Wallis and Fischer exact tests with correction on multiple comparisons, according to the Benjamini - Hochberg procedure with FDR $=0.2$ [11] were used to calculate differences between groups.

\section{Results and Discussion}

After the RE levels of 56 cancer- and immuneassociated genes were assessed in peripheral blood of experimental animals, we could divide the genes in three groups, (Figure $1 \mathrm{~A}$, B). Thus, the genes such as $C c l 5, I l 1 b$, Mif, Rnasel, S100al and Tgfbl were highly expressed, whereas the genes Erbb2, Ifnb1, Il6, Pdcdl and Prom 1 were low expressed genes. The RE levels differ between the highly and low expressed genes more than 100-fold.

13 genes were differently expressed, when the mice bearing melanoma cells were compared with the control animals, as was calculated by a statistical analysis. 11 genes were upregulated $(\mathrm{p}<0.05)$ (Table $1 \mathrm{~A})$ and 2 genes were downregulated $(p<0,05)$ (Table 1B).
Difference in the RE levels was considered significant, when the change was 2-fold or more. Several genes showed the tendency in changes, for example, $X d h(\mathrm{p}=0.055)$ and $\operatorname{Arg} 2$ $(p=0.058)$ were upregulated, and three genes, namely Ifng, Erbb2 ( $\mathrm{p}=0.055)$ and $I l 12 a$ $(p=0.057)$ were downregulated. We believe that in larger groups the changes in the RE levels could be significant.

The highest upregulation, above 3-fold, was found for $L b p, T l r 8, C x c l 9$, Oas $3(\mathrm{p}<0.001)$ in the mice, bearing melanoma cells.

The protein, encoded by $L b p$, is involved in the TLR signaling pathway and in the acute phase of the immunological response to gramnegative bacterial infections and also is a marker of fibril neutropenia and a poor state in cancer patients $[12,13]$. $T l r 8$ and $T l r 3$, receptors of the TLR family, were upregulated in the mice bearing melanoma cells. It was shown, that an increased expression of TLR 8 leads to a faster proliferation of tumor cells and also promotes chemoresistance of the pancreatic tumors. NF-kB and COX2 are upregulated with the TLR8 increase [14]. Moreover, it is known that TLR3 can stimulate invasiveness of cancerous cells [15].

Noteworthy, the expression levels and a role of $\mathrm{Cxcl} 9$ in the development of various tumor types is controversial [16]. Even so, Cxcl9 is a promising target for the creation of new approaches to treat cancer [17].

Among the interferon (INF alpha) targeted genes, Oas3, Oasla and Rnasel were upregulated in the group of mice bearing melanoma cells. Functioning of OAS1 and OAS3 in the immune pathways and response to RNA viruses are closely related to RNASEL [18]. It is known that downregulation of these genes 


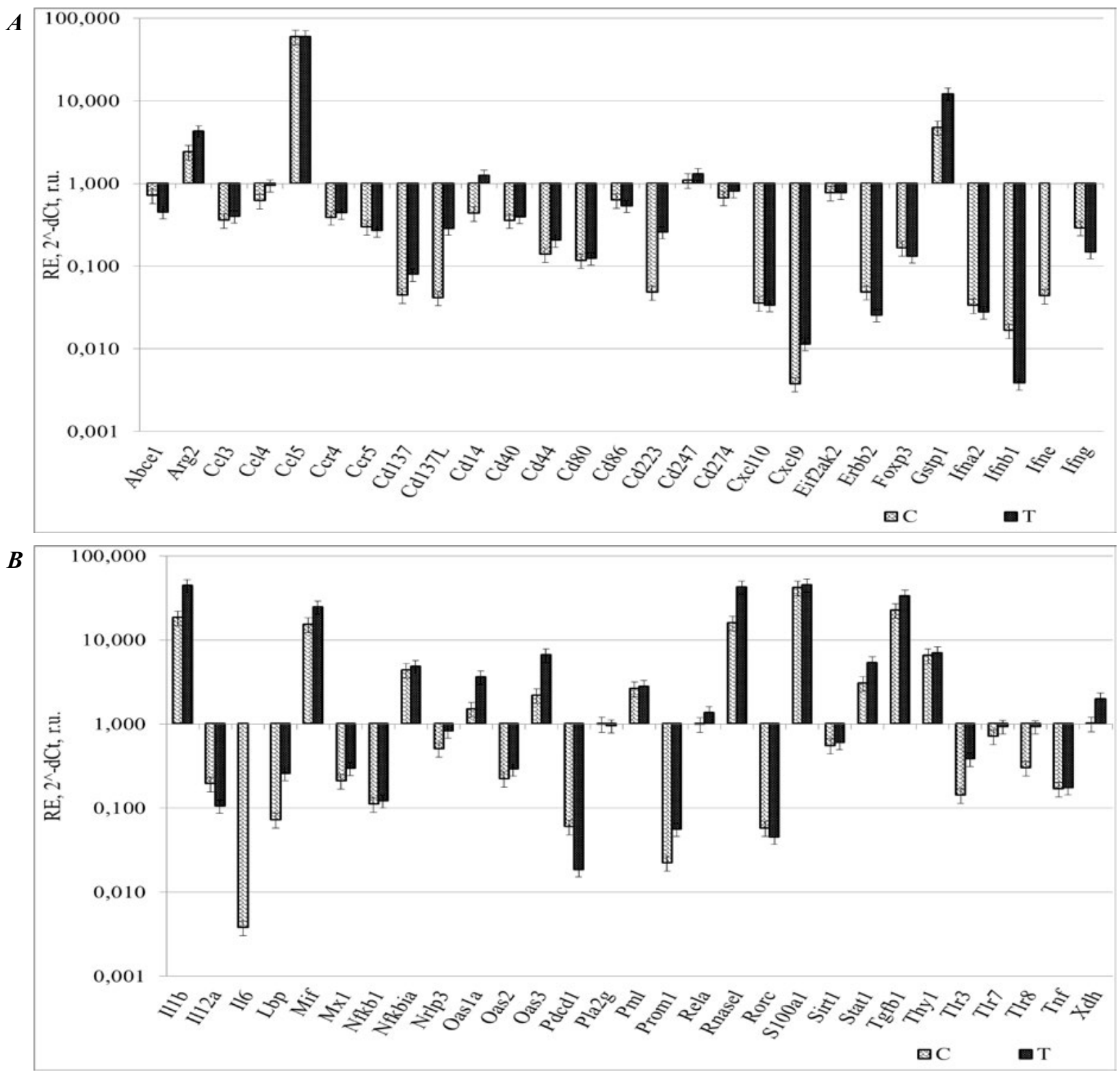

Fig. 1. Pattern of RE levels in the control mice (C) and mice, bearing melanoma cells (T).

is associated with the poor prognosis for cancer patients and also with the resistance to chemotherapy [19].

It could be that the mice still have the immune system reserves to fight the tumor growth at this stage after the melanoma cells were inoculated. However, several symptoms of the immunosuppressive state were detected in experimental animals, as was evident by the expression data.

Next, we observed a group of genes that showed moderate upregulation in the mice, 
Table 1.Gene RE levels, that were upregulated RE (A) and downregulated (B), when mice, bearing melanoma cells and the control animals were compared.

\begin{tabular}{|c|c|c|c|}
\hline № & Genes & $\mathrm{RE}$, increase & p-value* \\
\hline 1 & $L b p$ & 3.56 & \multirow{4}{*}{$\mathrm{p}<0.001$} \\
\hline 2 & Tlr8 & 3.10 & \\
\hline 3 & Cxcl9 & 3.04 & \\
\hline 4 & Oas3 & 3.01 & \\
\hline 5 & Cd14 & 2.89 & \multirow{7}{*}{$\mathrm{p}<0.050$} \\
\hline 6 & Tlr3 & 2.68 & \\
\hline 7 & Rnasel & 2.67 & \\
\hline 8 & Gstp1 & 2.55 & \\
\hline 9 & Prom1 & 2.51 & \\
\hline 10 & $I l 1 b$ & 2.42 & \\
\hline 11 & Oas1a & 2.40 & \\
\hline 12 & $X d h$ & 1.96 & $\mathrm{p}=0.055$ \\
\hline 13 & Arg2 & 1.77 & $\mathrm{p}=0.058$ \\
\hline
\end{tabular}

\begin{tabular}{|c|c|c|c|}
\hline № & Genes & RE, decrease & p-value* \\
\hline 1 & Ifnbl & 0.23 & \multirow{2}{*}{$\mathrm{p}<0.001$} \\
\hline 2 & Pdcdl & 0.31 & \\
\hline 3 & Ifng & 0.51 & \multirow{2}{*}{$\mathrm{p}=0.055$} \\
\hline 4 & Erbb2 & 0.52 & \\
\hline 5 & $I l 12 a$ & 0.54 & $\mathrm{p}=0.057$ \\
\hline
\end{tabular}

Note:* - Fisher exact test with FDR=0.2; genes, showing the significant differences in RE levels, are indicated in bold.

bearing melanoma cells, i.e. RE changes were 2-3 fold. The Cd14 upregulation could be due to the infiltration of monocytes into tumor, and could serve as a marker for cancer progression and metastasizing [20, 21].

It has been reported already that GSTP1, encoding Glutathione S-transferase PI, is overexpressed in many types of cancers [22], for example, is associated with the $\mathrm{K}$-ras mutation in colorectal cancer [23] and with downregulation of miR-133 $\alpha$ in head and neck squamous cell carcinoma [22]. An increased GSTP1 expression is also indicated in an enhanced detoxification activity, protecting cancer cells against cytotoxic and cytostatic drugs [24, 25]. However, there are no data on the Gstpl expression in the blood of cancer patients. Noteworthy, an increased GSTP1 expression enhances oncogenicity of breast cancer by regulating glycolytic and lipid metabolism as well as the energy and oncogenic signaling pathways, resulting in the activation of glyce- raldehyde-3-phosphate dehydrogenase [26]. Moreover, the genetic or pharmacological inactivation of GSTPI worsens the survival of tumor cells, due to abnormalities in the underlying signaling pathways.

PROM1 (CD133) is a marker of cancer stem cells, for lung and colorectal tumors [27, 28]. High levels are correlated with the poor prognosis in colorectal cancer [29]. Importantly, the increased RE levels of Proml were detected in the mice, bearing melanoma cells. This could be an evidence of the presence of circulating tumor cells in the mouse bloodstream as well as of an elevated expression of Cd14 and Gstp1, described above.

Additionally, the $I l 1 b$ expression increased in the mice, bearing melanoma cells. This interleukin can be expressed by tumor cells and different stromal elements, such as myeloidderived suppressor cells and tumor-associated macrophages [30]. IL1B enhances metastazing [31]. 
Importantly, the experimental animals, bearing tumor cells, showed lower RE levels of Ifnbl, Pdcdl and Ifng. This indicates the immunosuppressive state of the mice [32, 33].

Summarizing, several studied genes showed significant differences in the RE levels in the mice, bearing melanoma cells, compared with the control animals. The detected alterations refer to the genes, associated with the immune and cancer cells and could serve as putative noninvasive biomarkers of tumor growth. These genes are Lbp, Tlr3, Tlr8, Prom 1 and Cd14. Additionally, the Oas3, Rnasel, Gstp1 and $\mathrm{Cxcl} 9$ genes could be the markers of sensitivity to chemotherapy.

\section{Acknowledgments}

This work was supported by the Scientific Program of National Academy of Science of Ukraine "Molecular and cell biotechnology for medicine, industry and agriculture” №41/19.

\section{Conclusions}

Assessment of the expression of cancer- and immune-associated genes in the peripheral blood of the experimental animals upon the growth of malignant cells in vivo may result in the discovery of the effective noninvasive expression markers for the prognosis of the outcome of the cancer disease and effectiveness of the chemotherapy.

\section{REFERENCES}

1. Bastian BC. The molecular pathology of melanoma: an integrated taxonomy of melanocytic neoplasia. Annu Rev Pathol. 2014;9:239-271.

2. Bommareddy PK, Silk AW, Kaufman HL. Intratumoral Approaches for the Treatment of Melanoma. Cancer J. 201, 23(1):40-47.
3. Ma J, Guo W, Li C. Ubiquitination in melanoma pathogenesis and treatment.Cancer Med. 2017, 6(6):1362-1377.

4. Tímár J, Hársing J, Somlai B.Molecular classification and markers ofmalignant melanoma. Magy Onkol. 2013, 57(2):73-78.

5. Eriksson J, Le Joncour V, Nummela P, Jahkola T, Virolainen S, Laakkonen P, Saksela O, Hölttä E. Gene expression analyses of primary melanomas reveal CTHRC1 as an important player in melanoma progression. Oncotarget. 2016,7(12):1506515092.

6. Metri R, Mohan A, Nsengimana J, Pozniak J, Molina-Paris C, Newton-Bishop J, Bishop D, Chandra $N$. Identification of a gene signature for discriminatingmetastatic from primary melanoma using a molecular interaction network approach. Sci Rep. 2017,7(1):17314.

7. Melnichuk N, Kashuba V, Rybalko S, Tkachuk Z. Complexes ofOligoribonucleotides with d-Mannitol Modulate the Innate Immune Response toInfluenza A Virus H1N1 (A/FM/1/47) In Vivo. Pharmaceuticals (Basel). 2018,11(3). pii: E73.

8. Gerashchenko GV, Mankovska OS, Dmitriev AA, Mevs LV, Rosenberg EE, Pikul MV, Marynychenko MV, Gryzodub OP, Stakhovsky EO, Kashuba VI. Expression of epithelial-mesenchymal transitionrelated genes in prostate tumours. Biopolym. Cell. 2017,33(5):335-355.

9. Gerashchenko GV, Grygoruk OV, Kononenko OA, Gryzodub OP, Stakhovsky EO, Kashuba VI. Expression pattern of genes associated with tumor microenvironment in prostate cancer. Exp Oncol. 2018, 40(4):315-322.

10. Gerashchenko GV, Kononenko OA, Bondarenko YuM, Stakhovsky EO, Kashuba VI. Expression patterns of genes that regulate lipid metabolism in prostate tumors. Biopolym. Cell. 2018,34(6):445-460.

11. Benjamini Y, Hochberg Y. Controlling the false discovery rate: a practical and powerful approach to multiple testing. Journal of the Royal Statistical Society. 1995, 57: 289-300.

12. García de Guadiana-Romualdo L, Español-Morales I, Cerezuela-Fuentes P, Consuegra-Sánchez L, Hernando-Holgado A, Esteban-Torrella P, Jiménez-Santos E, 
Viqueira-González M, de Béjar-Almira Á, AlbaladejoOtón $M D$. Value oflipopolysaccharide binding protein as diagnostic marker of infection in adultcancer patients with febrile neutropenia: comparison with C-reactive protein,procalcitonin, and interleukin 6. Support Care Cancer. 2015, 23(7):2175-2182.

13. Fan Y, Yang L, Wei Q, Ding Y, Tang Z, Tan P, Lin T, Guo D, Qiu S. Toll-likereceptor 10 (TLR10) exhibits suppressive effects on inflammation of prostateepithelial cells. Asian J Androl. 2019, Jan 1. doi: 10.4103/aja.aja_100_18.

14. Grimmig T, Matthes $N$, Hoeland K, Tripathi $S$, Chandraker A, Grimm M, Moench R, Moll EM, Friess H, Tsaur I, Blaheta RA, Germer CT, WaagaGasser AM, Gasser M.TLR7 and TLR8 expression increases tumor cell proliferation and promoteschemoresistance in human pancreatic cancer. Int $J$ Oncol. 2015, 47(3):857-866.

15. Bugge M, Bergstrom B, Eide OK, Solli H, Kjønstad IF, Stenvik J, Espevik T, Nilsen NJ. Surface Toll-like receptor 3 expression in metastatic intestinalepithelial cells induces inflammatory cytokine production and promotesinvasiveness. J Biol Chem. 2017, 292(37):15408-15425.

16. Ding Q, Lu P, Xia Y, Ding S, Fan Y, Li X, Han P, Liu J, Tian D, Liu M. CXCL9: evidence and contradictions for its role in tumor progression. Cancer Med. 2016,5(11):3246-3259.

17. Tokunaga R, Zhang W, Naseem M, Puccini A, Berger MD, Soni S, McSkane M, Baba H, Lenz HJ. CXCL9, CXCL10, CXCL11/CXCR3 axis for immune activation - A target fornovel cancer therapy. Cancer Treat Rev. 2018, 63:40-47.

18. Choi UY, Kang JS, Hwang YS, Kim YJ. Oligoadenylate synthase-like (OASL) proteins: dual functions and associations with diseases. Exp Mol Med. 2015, 47:e144.

19. BanerjeeS, GushoE, GaughanC, DongB, GuX, Holvey-BatesE, TalukdarM, LiY, WeissSR, SicheriF, SaunthararajahY, StarkGR, SilvermanRH.OASRNase L innate immune pathway mediates the cytotoxicity of a DNA-demethylating drug. Proc Natl AcadSci U S A. 2019, 116(11):5071-5076.

20. Cheah MT, Chen JY, Sahoo D, Contreras-Trujillo H, Volkmer AK, Scheeren FA, Volkmer JP, Weissman IL.
CD14-expressing cancer cells establish the inflammatory and proliferative tumor microenvironment in bladder cancer. Proc Natl AcadSci U S A. 2015, 112(15):4725-4730.

21. Turrini R, Pabois A, Xenarios I, Coukos G, Delaloye JF, Doucey MA. TIE-2expressing monocytes in human cancers. Oncoimmunology. 2017, 6(4):e1303585.

22. Mutallip M, Nohata N, Hanazawa T, Kikkawa N, Horiguchi S, Fujimura L, KawakamiK, Chiyomaru T, Enokida H, Nakagawa M, Okamoto Y, Seki N. GlutathioneS-transferase P1 suppresses cell apoptosis and its regulation by miR-133ain head and neck squamous cell carcinoma (HNSCC). Int $\mathrm{J} \mathrm{Mol}$ Med. 2011, 27(3):345-352.

23. Miyanishi K, Takayama T, Ohi M, Hayashi T, Nobuoka A, Nakajima T, Takimoto R, Kogawa K, Kato J, Sakamaki S, Niitsu Y. GlutathioneS-transferase-pioverexpressioniscloselyassociatedwithKrasmutationduringhumancoloncarcinogenesis. Gastroenterology. 2001, 121(4):865-874.

24. Ruzza P, Rosato A, Rossi CR, Floreani M, Quintieri $L$. Glutathione transferases as targets for cancer therapy. Anticancer Agents Med Chem. 2009, 9(7):763-777.

25. Di Pietro G, Magno LA, Rios-Santos F. Glutathione S-transferases: an overview in cancer research. $E x$ pert Opin Drug MetabToxicol. 2010, 6(2):153-170.

26. Louie SM, Grossman EA, Crawford LA, Ding L, Camarda R, Huffman TR, Miyamoto DK, Goga A, Weerapana E, Nomura DK. GSTP1 Is a Driver of Triple-Negative BreastCancer Cell Metabolism and Pathogenicity. Cell Chem Biol. 2016,23(5):567-578.

27. Qiu ZX, Zhao S, Mo XM, Li WM. Overexpression of PROM1 (CD133) confers poor prognosis in nonsmall cell lung cancer. Int J ClinExpPathol. 2015, 8(6):6589-6595.

28. Ren F, Sheng $W Q, D u X$. CD133: a cancer stem cells marker, is used in colorectal cancers. World J Gastroenterol. 2013, 19(17):2603-2611.

29. Kashihara H, Shimada M, Kurita N, Iwata T, Sato H, Kozo Yoshikawa, Higashijima J, Chikakiyo M, Nishi M, Matsumoto N. CD133 expression is correlated with poor prognosis in colorectal cancer. Hepatogastroenterology. 2014, 61(134):1563-1567. 
30. Guo B, Fu S, Zhang J, Liu B, Li Z. Targeting inflammasome/IL-1 pathways forcancer immunotherapy. Sci Rep. 2016, 6:36107.

31. Tulotta C, Ottewell P. The role of IL-1B in breast cancer bone metastasis. EndocrRelat Cancer. 2018, 25(7):R421-R434.

32. Müller L, Aigner P, Stoiber D. Type I Interferons and Natural Killer Cell Regulation in Cancer. Front Immunol. 2017, 8:304.

33. Karachaliou N, Gonzalez-Cao M, Crespo G, Drozdowskyj A, Aldeguer E, Gimenez-Capitan A, Teixido C, Molina-Vila MA, Viteri S, De Los Llanos Gil M, Algarra SM, Perez-Ruiz E, Marquez-Rodas I, Rodriguez-Abreu D, Blanco R, Puertolas $T$, Royo MA, Rosell R. Interferon gamma, an important marker of response to immune checkpoint blockade in non-small cell lung cancer and melanoma patients. TherAdv Med Oncol.2018, 10:17588340-17749748.

\section{Патерни експресії імуно та пухлино- асоційованих генів у периферійній крові мишей 3 експериментальними меланомами}

Г. В. Геращенко, І. М. Вагіна, Ю. В. Вагін, 3. Ю. Ткачук, В. І. Кашуба

Мета. Визначити потенційні неінвазивні експресійні маркери на основі патернів відносної експресії (BE) пухлино- та імуно-асоційованих генів, що вивчались у периферійній крові мишей з введеними клітинами меланоми. Методи. Рівні ВЕ пухлино- та імуно-асоційованих генів були досліджені кількісною ПЛР у периферійній крові C57BL/6j мишей з введеними В16 клітинами меланоми та контрольних тварин. Результати. Для 11-и генів виявлено значущі відмінності рівнів ВЕ у мишей з введеними клітинами меланоми, з них 6 генів (Ccl5, Illb, Mif, Rnasel, S100a1 та $T g f b 1)$ мали підвищені рівні BE та 5 генів (Erbb2, Ifnb1, Il6, Pdcd1 й Prom1) - знижені рівні BE у порівнянні 3 контрольними тваринами. Ми показали стабільний імуносупресивний стан мишей з введеними клітинами меланоми, про що свідчать знижені рівні ВE Ifnbl, $P d c d 1$ та підвищені рівні BE Lbp, Tlr3, Tlr8, Gstp1, Prom1, Oas1a, Oas3 таIllb. Висновки. Оцінка експресії пухлино- та імуно-асоційованих генів у периферійній крові експериментальних тварин при прогресії у них злоякісних клітин може призвести до виявлення ефективних неінвазивних експресійних маркерів для прогнозу онкологічних захворювань та ефективності хіміотерапії.

К л юч о в і с л о в а: меланома, відносна експресія генів, імуно-асоційовані гени, потенційні експресійні маркери.

\section{Паттерны экспрессии иммуно и опухоль- ассоциированных генов в периферической крови мышей с экспериментальными меланомами}

А. В. Геращенко, И. Н. Вагина, Ю. В. Вагин, 3. Ю. Ткачук, В. И. Кашуба

Цель. Определить потенциальные неинвазивные экспрессионные маркеры на основе паттернов относительной экспрессии (ОЭ) опухоль- и иммуно-ассоциированных генов, которые исследовались в периферической крови мышей с введенными клетками меланомы. Методы. Уровни ОЭ опухоль- и иммуно-ассоциированных генов были исследованы количественной ПЦР в периферической крови of C57BL / 6j мышей свведенными В16 клетками меланомы и контрольных животных. Результаты. Для 11-и генов выявлены значимые отличия уровней ОЭ у мышей с введенными клетками меланомы, из них 6 генов (Ccl5, Illb, Mif, Rnasel, S100al и $T g f b 1)$ имели повышенные уровни ОЭ, а 5 генов (Erbb2, Ifnb1, Il6, Pdcd1 и Prom1) - пониженные уровни ВE по сравнению с контрольными животными. Мы показали стабильное иммуносупрессивное состояние мышей с введенными клетками меланомы, о чем свидетельствуют сниженные уровни ОЭ Ifnbl, Pdcdl и повышенные уровни ОЭ Lbp, Tlr3, Tlr8, Gstp1, Prom1, Oas1a, Oas3 и Illb. Выводы. Оценка экспрессии опухоль- и иммуно-ассоциированных генов в периферической крови экспериментальных животных при прогрессии у них злокачественных клеток может привести к выявлению эффективных неинвазивных экспрессионных маркеров для прогноза результата онкологических заболеваний и эффективности химиотерапии.

Кл юч е в ы е с л ов а: меланома, относительная экспрессия генов, иммуно-ассоциированные гены, потенциальные экспрессионные маркеры

Received 01.05.2019 